「森林水文」特集

\title{
森林土袞の流出緩和効果に関する 研究の展開過程
}

\author{
谷誠 1$)^{\dagger}$ \\ 1）人間環境大学 \\ (₹ 444-3505 愛知県岡崎市本宿町上三本松 6-2)
}

†連絡先著者 (Corresponding Author) E-mail : m-tani@uhe.ac.jp

\begin{abstract}
森林土壤の流出緩和効果について, 浸透能, 保水容量に基づく通説を紹介した後, 山腹斜面の流出機構に関する 理解にともなって進展してきた評価手法を解説した．土壤の効果はその間隙分布からもたらされる保水・透水特性 に基づくのであるが，具体的には，降雨を吸収して洪水流出総量を減らす効果と降雨波形を緩やかにして流出ピー クを低くする効果として現れる，後者の効果は，パイプ状水みちや土層下側の風化基岩層の中の流出機構によって 影響を受けるが, 生物によって大間隙が形成され，土層発達にともなってパイプ状水みちが形成される長期過程を 考慮すると, 結果的に森林土壤の洪水流出緩和効果が発揮されたとみなすことができる.
\end{abstract}

キーワード : 森林影響, 土壤物理性, 流出緩和, 斜面水文学, 不均質性

\section{I 、はじめに}

森林の水源涵養機能に関しては, 科学的に合理的 な説明が前提となる西欧の風土に対して, 日本やア ジアなどでは人間に有利な機能が信じられやすい風 土がある（Komatsu and Rappleye, 2017）。例えば, 水 資源利用において重要な無降雨時の基底流出量は, 森林伐採によって増加し, 森林の繁茂によって減少 することは, 森林水文学研究によって明らかになっ ているにもかかわらず（Swank and Douglass, 1974; Bosch and Hewlett, 1981), 必ずしも一般社会に受け 入れられていない.こうした期待は, Calder (1999), チャペル（2005), Sidle et al. (2006) などの水文学 者によって, 神話として否定されている。だた, こ のような論説があること自体，欧米社会にも森林効 果に関する通説が根強いことを逆説的に示すように も思われる。いずれにせよ，伐採によって蒝発散が 減り，水資源利用に貢献することは明らかであり， 人工林が収穫期に達している日本において，筆者は 伐採の効果としてむしろ積極的に活用すべきと考え ている（谷ら, 2017 ; 谷, 2017).
しかし, 以上の森林とその伐採が流出に及ぼす影 響は, 蒸発散量変化を基に現れるものであり, 森林 の影響はそれにとどまるわけではない，洪水流出の 総量やピークを小さくして基底流出量を大きくす る, いわゆる保水力や緑のダムと呼ばれる流出緩和 効果は, 土壤や風化基岩を含む斜面地下での雨水貯 留特性を通じてもたらされる。ただ，国際的には， 森林変化が大流域の洪水流出低下に影響を及ぼすか どうかに注目する研究がある一方 (Bradshow et al., 2007; Laurance, 2007), 斜面での水文観測研究の関心 は, 森林の洪水流出緩和効果の評価には置かれず, 斜面毎の流出機構の特徵を観測によって抽出する, いわば地理学的な関心が高いようにみえる（Torres et al., 1998; Tromp van Meerveld and McDonnell, 2006). 筆者は, 雨水が森林土壤を通ることによって洪水流 出量が人間社会にとって好都合な形に変化するとい う洪水流出緩和効果を土壤物理性を基礎に評価しょ うとする研究は日本の㧍家芸たと捉え, この効果に 関する科学的見解を, 持続的林業や森林減少問題の 重要性にかんがみ，国際社会に発信してゆかなけれ 
ばならないと考えている，蒸発散に加えて流出過程 における森林の効果が評価できてはじめて, 水循環 を重視した森林管理が可能になるのである.

さて土壤の流出緩和効果の評価について, 藤枝 （2007）は，土壤の保水容量による評価と降雨流出 応答関係からの流域貯留量による評価が別々に検討 されてきたと述べている。しかし，この区分は，そ れぞれの研究分野での調查結果に対応しているのに 過ぎず，評価は本来統合されるべきであろう。筆者 は，土畩の流出緩和効果の評価手法がどのような流 出機構に基づいているのかを包括的に理解すること が重要だと考えている。そこで本稿では，まず土壤 効果の評価手法に関する通説を紹介した後, 流出機 構についての理解の進展を基にした評価手法の最前 線について説明してゆきたい.

\section{II．土堙間隙と地中の流れの分類}

降雨流出機構を調べるには, 地中での水の動きを 扱う必要があるが, 斜面水文学の発展過程から subsurface flowなど独自の用語が用いられ，水理学や 土壤物理学での表現との対応がわかりにくくなって いる．地中での水の動きは複雑で多様な流れのすべ てを説明することは困難であるが（Beven and Germann, 2013）, ここでは, 土壤の流出緩和効果を考えるう えで必要な間隙と流れの分類を行ってみたい.

土壤水を特徵づけるのは, 多孔質媒体としての土 壤が表面張力によるマトリックポテンシャルにより 土粒子表面やその間隙に水を吸引していることであ る。毛管水縁のようにたとい間隙が飽和してはいて も, このポテンシャルを持つ部分を不飽和帯と定義 する。自然土壤の中には，間隙の連結したパイプ状 の水みちなどを含むサイズの大きな間隙が存在す る。本稿では，これらすべてをマクロポアーとみな すが, マクロポアーをふたつに区分して考えてゆく。 すなわち, 圧力水頭が正の值を持つ飽和带でなけれ ば水がはいらないパイプ状の水みちと, 負の圧力水 頭を持つ不飽和帯であっても圧力水頭がゼロに近い 飽和近くであれば水がはいる大間隙とを区別して扱 う。ダルシーの法則によると, 飽和帯であっても不 飽和帯であっても, 流量が圧力水頭と位置水頭の和 で表現される水理水頭の勾配に比例する。この法則 が成り立つ飽和帯の流れを飽和浸透流, 不飽和帯の 流れを不飽和浸透流，まとめて飽和不飽和浸透流と 呼ぶ。なお, 飽和浸透流は, 地下水面のあるなしで,
不圧地下水流と被圧地下水流に分類されるが，本稿 では, 名称整理の観点から地下水流の表現を避け, 飽和浸透流の用語を用いることにする。一方，土壌 に含まれるパイプ状水みちにおいては, 流量はダル シーの法則からはずれ，マニング式にしたがうよう に変化する (北原, 1994)。また水みちでは, その間 隙内に大気圧に等しい空気がはいっていて水面を持 つ開水路として扱われる場合も，間隙内に水面がな い管水路として取り扱われる場合も起こり得る（堤 ら, 2005)。これらのパイプ状水みち内の流れをまと めてパイプ流と呼んでおく。また, 先に述べた subsurface flow は, 斜面方向に向かう流れの総称で, 不飽和浸透流，飽和浸透流，パイプ流などから成る とみなしておく。

なお,ダルシーの法則を前提とした場合でも，不 飽和浸透流と飽和浸透流の組み合わせとその流れの 向きは降雨強度によって変化する。すなわち, Tani （2008）のRichards式を用いた理論的解析によると, 降雨強度が極端に弱い場合には, 土層の大部分は斜 面方向の不飽和浸透流に扮扮われる。しかし, 通常 の降雨強度の範囲では, 地表面からの鉛直不飽和浸 透流が生じ, ある梁さで斜面方向に流れの向きを変 え, 斜面方向への浸透流は地下水面をはさみ不飽和 部分と飽和部分とから構成されると考えてよい. 現 実には地中の流れは非常に複雑ではあるが, 本稿で は飽和不飽和浸透流を主たる解析対象とし, 加えて パイプ状水みちの役割を考慮することによって, 土 壤の流出に及ぼす効果を考えてゆく。

\section{III. 土壤の流出緩和効果の通説}

\section{1. 浸透能に基づく評価}

まず，古典的な浸透能による評価について述べる． Horton（1933）の示唆した, 地表面における浸透能 を超えて発生するホートン地表面流が洪水流出にな るとの流出機構を前提にすれば，図一1のように, 地表での浸透能が大きいほど流出緩和効果が大きい と考えられる（村井・岩崎, 1975）。しかし，かなり 早い時期の観測研究によって, 湿潤温帯における森 林斜面での浸透能は降雨強度よりも十分大きいので 降雨のほとんどが土壤内に浸透することがみいださ れ (Hewlett and Hibbert, 1967), 浸透能によって洪水 流出・基底流出を分離する考えに無理があることが わかってきた。

そこで，いったん地中内にはいった雨水の一部が 


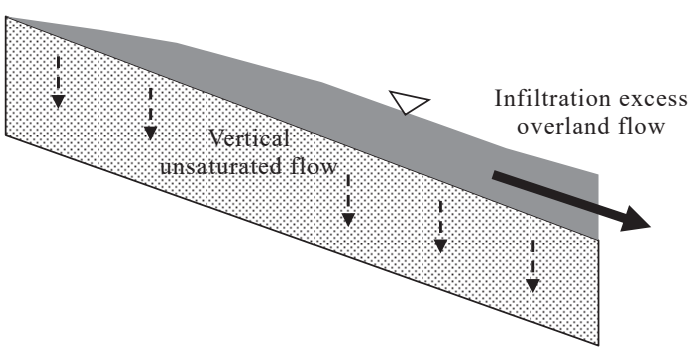

図－1 ホートン地表面流による洪水流出の概念図

Fig. 1 Schematic showing stormflow mechanisms by infiltration excess overland flow.

洪水流出を引き起こし, 降雨とともに洪水流発生域 が拡大してゆくものと考えられるようになった (Kirkby, 1978). その結果, 土層内の地下水面上昇に よって発生する飽和地表面流が洪水流出を産み出す との考えが広がった（Dunne and Black, 1970）。しか し, 降雨期間中の洪水流出水に降雨前から地中に貯 留されていた「古い水」が多く含まれること（Pearce et al., 1986）がわかってくると, 土壤マトリクスよ りも高速の流れを産み出すパイプ流がかかわり, 降 雨による「新しい水」が周囲の土壤水と混ざって古 い水による洪水流出が産み出すされると考えられよ うになった（McDonnell, 1990).

こうした観測研究は, 米国やニュージーランドな どの山地流域で行われたが, 日本でも，後述のよう に, 洪水流出は地表面流によってもたらされるので はないと考えられた（窪田ら, 1987 ; Tsukamoto and Ohta, 1988).ところが, 2000年代になって, 間伐が なされずに下草が生えずに林床が裸地化した人工林 では地表面流が発生しやすくなることが指摘され た。この問題意識での一連の研究をとりまとめた恩 田（2008）の書物では, 地表面流が中小降雨におい て頻繁に発生することが強調されている。ただ，大 雨時に関する限り, 小松ら（2013）も指摘するよう に, 必ずしも裸地化された人工林で地表面流が大き くなるとの傾向は得られていない. 現在のところ, 地表・土層・風化基岩層のそれぞれで, 多様な流れ が生じ，かつ混合することで洪水流出が産み出され るとの考え方が, 斜面水文学の共通認識になってき たと, 筆者は理解している (Gomi et al., 2010; McDonnell and Beven, 2014 ; Iwasaki et al., 2015, 谷, 2016a).

確かに住宅団地として開発された都市化流域では 浸透能が小さくなり, 雷雨のような総量は多くない が強度の強い降雨の時には, 森林に比べてはるかに
大きなピーク流出強度を持つ洪水流出が発生する (立川ら, 2009)。そそれゆえ, 浸透能が小さいことが 洪水を大きくすることに結びつく，一方，森林の場 合には土壤に浸透した雨水の一部も洪水流出になる のだから, 浸透能が大きいことと洪水流出緩和効果 が大きいこととは必ずしも対応しない. だが，森林 の浸透能が大きいことで洪水流出緩和効果を評価す る通説も一般社会では根強い（上野・南, 2016）.

\section{2. 保水容量に基づく評価}

雨水の多くが地中に浸透するとすれば，その浸透 水が基底流出に多く, 洪水流出に少なく配分される ことが，流出緩和効果を大きくするであろう，それ にかかわる森林土壤の物理特性については, 戦後の 早い時期から, 森林の立地条件の空間分布を明らか にする林業上の必要性に基づいて, 林業試験場（現 在の森林総合研究所）を中心に精力的に研究が進め られた（真下, 1960)。これを背景にして, 土潩間隙 径の範囲によって流出緩和効果を表現する研究が展 開された (有光, 1992). どの範囲の間隙量を持って 流出緩和に有効な保水容量とすることができるかに ついては, いくつかの考え方があり, 藤枝 (2007) によって整理されているので, 参照いただきたい.

さて, 保水容量としてどの範囲の間隙量が適切な のか, あるいは風化基岩層をも評価に加えるべきか の判断は容易ではない。 そこで, 流域土壤の間隙特 性と流域からの流出量の変動特性の対応を比較検討 する研究が行われた，その流域レベルの検討におい ては, 志水（1980）や虫明ら（1981）による山地河 川流域の流況解析の結果, すなわち, 地質の影響が 統計的に明瞭に抽出されるとの結果は, 重要な情報 を与えた。つまり, 火山灰や火山砂礫などの間隙率 が大きくて巨大な地下水帯を形成している第四紀火 山や風化基岩層が厚い花崗岩山地では, 中古生層山 地に比べて流況が安定している。 それゆえ, 森林生 態系の活動によって形成される表層土畩の保水容量 というよりは, より深層の地下構造が流出緩和効果 に反映されるのではないか, との推測が妥当のよう に思われた（虫明, 1981)。たた，表層土畩の間隙分 布すなわち圧力水頭と体積含水率との関係は, 地質 に依存する傾向も指摘されている(有光, 1992). 地 質による洪水流出緩和効果には, 土層と基岩層の両 方がかかわっているらしいということになる.

しかし, 保水容量が洪水流出緩和効果を産み出す メカニズムについては. 十分検討が進められたとは 
いえない，そのため，地表面の浸透能の場合と似た 推測,「土壤の保水容量が大きい場合に流出緩和効 果が大きいだろう」という推測だけがひとり歩きし, 通説として社会に広がってしまったように考えられ る。土壤の間隙特性と流出緩和効果の関倸について は，その根拠となる水移動機構の解明がやはり必要 なのである。

\section{IV．斜面の流出機構に基づく土壤効果の 評価}

\section{1. 浸透流説と水みち説}

マクロポアーが含まれ，不均質性の大きい森林土 壤での水の流れ方は確かに多様なのではあるが (Liang et al., 2011; Beven and Germann, 2013)， II でも ふれたように，水理水頭勾配の小さい方向に水が浸 透するという多孔質媒体での水理学的法則を基盤と して検討して良いと，筆者は考えている。こうした 水理学的な基本が水文学で必ずしも共有されていな いことが，長い間，雨水流出過程の正当な理解を妨 げてきた，というのは，降雨流出応答をもたらす水 理学的なメカニズムとして, 降雨時に一時的に発生 する飽和浸透流を重視し, 不飽和浸透流の役割を 「特段の根拠なく無視する考え方」がむしろ常識で あったからである（高木・松林, 1979, Harman and Sivapalan, 2009 ; Troch et al., 2003).

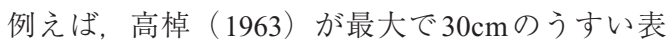
層を「A層」と表現し, そこでの飽和浸透流の発達 を考えた場合のように，対象とする土層がきわめて うすく, 鉛直不飽和浸透流の生じる長さが無視でき るほど小さいという前提が満たされた場合に限って は，こうした近似が可能かもしれない。ところが, このうすい表層は, 森林土壤学の定義では, 有機物 の多い $\mathrm{A} 0$ 層ないし $\mathrm{A}$ 層とみなされるが, 加藤ら （1975）の斜面観測によれば，その内部では斜面方 向の飽和浸透流がほとんど発生しなかった。土層と 風化基岩の境界付近で初めてこれが発生するようで あった，その境界までは， $\mathrm{B}$ 層・C 層とを合わせて $1 \mathrm{~m}$ 前後の厚さの土層があるのが普通であるから, 一般には，その発生域に至るまでの鉛直不飽和浸透 流の役割を決して無視できない，飽和不飽和浸透流 を飽和浸透流で近似するためには，水理学的な吟味 が不可欠なのである（Brutsaert, 2005).

また，これまでの流出過程のモデル化では，飽和 不飽和浸透流の基礎式の解が容易に得られないこと
を理由として，不飽和带を無視して飽和浸透流を扱 うことが多かった (Brutsaert, 1994). さらに, 水文 学の教科書（Brutsaert, 2005; 椎葉ら, 2013）では, 一般に, 降雨に対する洪水流出応答をもたらすメカ ニズムと飽和不飽和浸透流の水理学とが別々の章に 配置され，相互の関連が重視されなかった。実際に は，飽和帯と不飽和帯は相互依存の関係にあるとい わなくてはならない.

そこで, 流出機構と流出モデル開発に大きな影響 を及ぼしたFreeze（1972）による斜面土層の三次元 飽和不飽和浸透流計算に立ち返り，不飽和浸透流を 無視せずに降雨流出過程を検討する. Freezeの研究 の重要性は, 通常の飽和透水係数を持つ物理性の均 質な土層を対象としたとき，洪水流出ハイドログラ フの急激な時間変化が土層内の浸透流では説明でき ないことを明らかにしたところにある。すなわち 図一2Aのように，土層内の流机は洪水流出を産み 出すには遅すぎるので，地下水流机が停滞して水面 が上昇して地表からあふれ, 飽和地表面流が発生す る。その発生場に降る雨水が加わって地表を速く流 れ，洪水流出を産み出すわけである。この結果は, 逆にいえば，土層内部にパイプ状水みちがあって周 辺土壤よりも高速な流れが生じるときには，それに よって洪水流出応答が説明できることをも意味し (図一2B)，実際，そうした不均質性の重要性が 1980 年頃以降の観測によって指摘されてきた（Mosley, 1979 ; 塚本ら, 1988 ; McDonnell, 1990).

なお，Freezeの計算で発生する飽和地表面流は， 石原ら（1962）や高棹（1963）が考えているA層飽

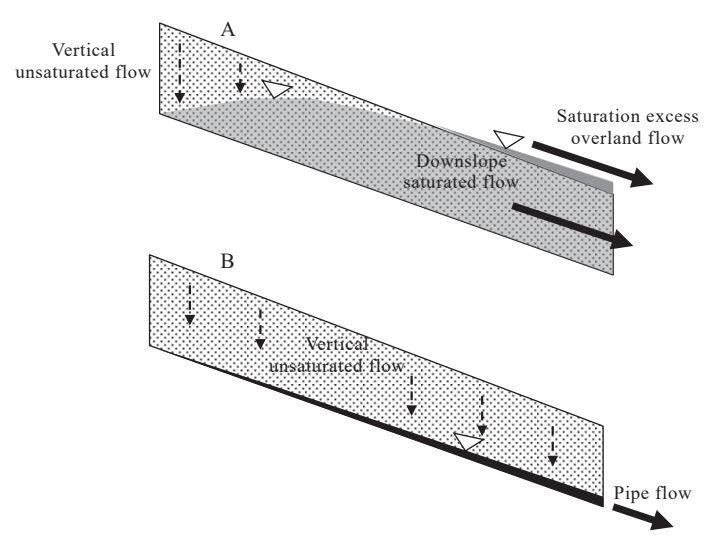

図-2 飽和地表面流による洪水流出（A）とパイプ状 水みちによる洪水流出（B）の概念図

Fig. 2 Schematics of stormflow mechanisms by saturation excess overland flow (A) and pipe flow (B). 
和での地表面流とは，土層飽和によって発生する点 は同じであるが，鉛直不飽和浸透流が前提になって いるかどうかの点で区別される。飽和不飽和浸透流 を前提に考える前者では，水みちがある場合にそれ を通して地下水が高速排水されるならば，水みちに 至るまでの鉛直不飽和浸透流を通じて, 土層の厚さ や土壤物理性が洪水流出応答に影響を及ぼす可能性 がでてくる.しかし, 石原ら（1962）のモデルでは, 鉛直不飽和浸透流の役割を想定していないという, 両者の差異にご留意いただきたい.

以上のことから, 洪水流出や基底流出を産み出す メカニズムとして, Freeze（1972）のように, 均質 土壤での飽和不飽和浸透流を前提に説明してゆこう とする考え方と，土層内でパイプ状水みちによる高 速排水があるとの考え方が区別される。本稿では, 前者を「浸透流説」, 後者を「水みち説」と呼びた い.もとより土層は空間的に不均質で複雑であるか ら，この区別は説明の都合上のものである。そこで 次節では, 浸透流理論と観測研究の両面から展開さ れてきた, 土壤や地形条件の流出影響への評価研究 の流れをたどってみよう。

\section{2. 飽和不飽和浸透流の取り扱い方法の模索}

飽和不飽和浸透流は, その非線形性が強いことの 結果として, 現在でもその降雨流出応答に及ぼす影 響がよく理解されていない。この点は, 土壤や地形 の流出に及ぼす影響を考える上で障壁である。しか し, 浸透流の性格を解明しようとする研究は, すでに 1980年代から始まっているので, ここで紹介したい.

降雨時に抢ける不飽和带の水の挙動については, 土壤物理学分野では, ウェッティングフロントの進 行によって特徴づけられる（八幡, 1975).すなわち, 乾燥した砂質土壤に降雨があると, 雨水のほとんど は地表面付近の土壤に吸収される。その雨水を吸収 した湿潤土壤と下側の乾燥部の間にできる不連続な 面としてウェッティングフロントができ, 降雨が続 くとフロントが鉛直に下降する。そのため, 雨水は すべて土壤内のフロントより上側に閉じ込められ て, 基岩表面などの透水性の低下する面にフロント が到達するまでは, 飽和浸透流を産み出すことがな い。こうした土壤物理学の知見を背景に, 水文学で は, 鉛直不飽和浸透は降雨のうち洪水流出には寄与 しない「損失」として扱われることが多かった（石 原ら, 1962 ; 椎葉ら, 2013).

これに対して, 谷 $(1982 ; 1985)$ は, 飽和不飽和
浸透流は乾湿状態によって一見質的に異なるふるま いを生じさせること，すなわち，土㙵物理条件，初 期条件, 降雨条件によっては, 洪水流出八イドログ ラフを産み出す性質があることを示した，具体的に， 次のリチャーズ式の一次元鉛直浸透流の式形によっ て説明しょう.

$C \frac{\partial \psi}{\partial t}=\frac{\partial K}{\partial z}+\frac{\partial}{\partial z}\left\{K\left(\frac{\partial \psi}{\partial z}\right)\right\}$

ここで, $\psi$ は圧力水頭, $K$ は透水係数, $C(=d \theta / d \psi)$ は比水分容量, $\theta$ は体積含水率, $z$ は上向きを正とす る鉛直座標, $t$ は時間である.

谷（1982）は，（1）式の右辺第一項が重力によっ て生じる移流項, 第二項が拡散項であることに基づ いて, 土層底面が降雨の影響を受けて地下水面が発 生する時刻が, 土䁃物理条件によって非常に異なる ことを論じている。すなわち, $\psi$ の飽和に近い值付 近で $\theta$ が大きく変化するような砂質土では, ウェッ ティングフロントが明瞭に生じて, 降雨の影響はフ ロントが深部に伝わるまでに時間がかかり, 地下水 面はなかなか上昇を開始しない. しかしいったん上 昇を始めると, 不飽和帯の含水率がすでに飽和に近 くなっているために，わずかな降雨量の追加によっ て一気に上昇する。これに対して， $\theta$ の $\psi$ に対する 変化が小さいような粘土質土では, 拡散効果が大き くなり，フロント形成は不明瞭になって降雨の影響 は深部に早く伝わるが, 地下水面上昇はかえって緩 やかになる。こうした解析の結果, 土䁃の性質が土 層底面での飽和帯の発生とそれへの水供給に大きな 違いを産み出すという, 鉛直不飽和浸透流の非線形 な性格が明らかになった。

谷（1985）は, この議論を発展させ, 鉛直不飽和 浸透流によって土層底面の飽和帯へ供給される排水 強度の非線形性を検討し, 降雨総量が大きいと洪水 流出に相当する速やかな排水応答を示すが, 降雨総 量が少ないと洪水流出の時間スケールよりはるかに 遅い排水応答しか産み出さないこと, この傾向は非 線形効果の強い砂質土が粘土質土よりも著しいこと を示した。降雨総量の違いによって, 洪水流出に寄 与することもある一方, 寄与しないで終わることも あるわけで, 鉛直不飽和浸透流は, 雨水の洪水流出 と基底流出への分配に対しても, 降雨から流出への 波形変換にも, 重要な役割を果たすことが指摘され たわけである.

さて, 鉛直不飽和浸透流が洪水流出と基底流出の 両方を産み出すことがあり得るのは, 体積含水率の 
変化にともなって飽和透水係数が何オーダーも変化 することから生じる極端に強い非線形性があること によっている(谷, 2016b)。それゆえ, 湿潤な土壤 に貯留された水は, 降雨後, 比較的大きなサイズの 間隙から速やかに排除され，その後細かい間隙から のゆっくりした排水が続く、それゆえ, 土壤物理性 の均質な斜面上の二次元土層を湿潤状態にし，それ を初期条件にして斜面下端からの流出量を自然減衰 させると，速やかな減衰がまず生じ，引き続き，緩 やかな減衰が長く続く。鈴木（1984a）は，この減 衰が, 体積含水率と不飽和透水係数の関係によって 主に支配されることをみいだした。また鈴木 (1984b) は, この流出減衰特性に対する蒸発散の影響を解析 した。 その結果, 斜面土層からの飽和不飽和浸透流 計算によって, 蒸発散の多い夏が冬よりも減衰勾配が 急になるという小流域の観測結果がよく説明された。

水文学ではすでにV.1で述べたように，不飽和帯 の水移動を無視して飽和浸透流である地下水流に よって流出応答や減衰の特性が解析されることが多 い.しかし, 急傾斜の斜面土層は降雨終了後しばら くすると不飽和帯に抄抄われる。したかって, 蒸発 散による水消費を受けつつ流れる斜面方向の不飽和 浸透流によって基底流出が産み出されるのであり, 飽和浸透流がこれを産み出すのではない。不飽和帯 の水移動を無視して通常地下水流と呼ばれる飽和浸 透流だけを対象とすることは確かに「計算上は」可 能であるが, それでは, 実際の不飽和浸透流に基づ く流出機構を水理学的に近似したことにはならない のである.

さて, IV.1で述べた「浸透流説」と「水みち説」 の区別からみたとき，谷 $(1982 ； 1985)$ は，一次元 鉛直不飽和浸透流からの排水への土壤物理性や土壤 厚さなどの影響を検討している点で, 水みちを通じ た飽和帯内の水の高速排水を暗黙の前提としている と考えられ, 水みち説に属している。一方, 鈴木 （1984a：1984b）では，水みちを含まない二次元飽 和不飽和浸透流計算を行って基底流出が解析されて いるので, 浸透流説に属している. 当時, 鈴木が リーダーであった京都大学の森林水文グループで は, これらの考え方と斜面での観測結果との対応が 検討された (谷, 2016a).

太田ら（1983）は, 花崗岩山地の斜面幅 $2.2 \mathrm{~m}$, 斜面長 $4.8 \mathrm{~m}$, 平均勾配 $32^{\circ}$, 平均土䁃厚さ $30 \mathrm{~cm}$ と いう非常に小さいスケールの斜面で, 降雨のハイエ トグラフから洪水流出のハイドログラフへの波形変
換の観測結果が, 鉛直不飽和一次元浸透流と斜面方 向の飽和浸透流の組み合わせによって再現できるこ とを示した。 こうしたうすい土層であっても, 洪水 流出波形変換において鉛直浸透過程が重要な役割を 果たすことが説明されており, 飽和浸透流を考慮し ているとはいえ, 水みち説を支える結果だと考えら れる。一方, 窪田ら（1987）は，ゼ口次谷流域にお いて, 土層の飽和不飽和浸透流を近似した鈴木 （1984a）のモデルで, 洪水流出と基底流出の全体を 再現することができ，しかも，それは土壤水分量の 空間分布と対応していたことを明らかにしている. これは浸透流説に属する。ところが，モデル計算で は, 飽和透水係数を鈴木（1984b）よりも30倍ほど 大きい值を採用して㧍り, この工夫によって, 基底 流出だけでなく, 洪水流出を計算することができた と推測される。こうした工夫を行わなかったとする と, Freeze (1972) の計算が示すように, 降雨期間 に飽和地表面流が発生してしまう可能性がある。だ が観測によると，実際は土層内の流れで洪水流出が 生じていたのであるから, 純粋に浸透流説というわ けではなく, 水みちがかかわる速やかなパイプ流を 想定していたとも考えられる。

以上のように, 基底流出に関しては, 浸透流説で の飽和不飽和浸透流としての扱いに無理はないとし ても, 地中の流れで洪水流出を説明するには, 速度 の大きい流れが存在し，その役割を評価せざるを得 ないのではないかと, 当時考えられたのである.

\section{3. 土壤間隙を満たす貯留量指標に基づく評価}

III. 2 に㧍いては, 土壤の間隙分布から得られる保 水容量によって流出緩和評価の基準とする方法が流 出機構に照らして妥当かどうか, ただちには判断し にくいとの説明を行った。 土畩物理性は, 保水特性 と透水特性とから成り, 前者は圧力水頭 $\psi$ と体積含 水率 $\theta$ の双方に時間の次元が含まれないことからわ かるように，時間と無関係な静的な関係に基づいて いる. 一方後者, 透水特性は, 時間の次元を含む不 飽和透水係数 $K$ 間変化を表現する。いずれも土壤間隙サイズの分布 によって決まる性質であるが, 保水容量は保水特性 の範疇に属し透水特性の影響を受けないため, 貯留 量の時間変化が表現されないわけである。そそこで流出 に扔ける時間変化を考慮して土壤効果の評価を行っ た小杉賢一朗の研究を，本節と次節で紹介したい．

小杉（1999）は，一次元鉛直不飽和浸透流で土壤 
の流出緩和効果を論じている。この研究では, 土層 底面の圧力水頭をゼロとした静止平衡条件を初期条 件として, 一定強度の降雨を与え続けたときに土層 に貯留される水量で定義される「貯留量指標」の大 きさで洪水流出量の緩和を評価する手法が採用され ている. 貯留量指標は, 団粒構造や砂質などのサイ ズの大きな間隙の多い土壤が, カべ状や粘土質の細 かい間隙に富む土畩に比べて大きく，土層からの排 水強度の時間変化が緩和され, そのピークが低くな る傾向が指摘された。

この論文では, 降雨強度が大きい場合に貯留量指 標が大きくなる透水特性が反映されており， III.2で 説明した静的な保水容量との評価の違いが指摘され ている。たたし, 保水容量, 貯留量指標にかかわら ず，サイズの大きな間隙が多く含まれていることが 流出緩和効果を高くする点は同じである。またいず れの考え方も, 結果的に「水みち説」を流出機構の 前提としており，鉛直不飽和浸透流を通じて土㙵物 理性や土層の厚さの影響が流出特性に現れるという 点も共通している。逆にいえば, 水みち説を採用し ない場合は, 斜面の長さや勾配等の地形条件もかか わってきて複雑になり, こうした評価はそのまま活 かせないのではないか, という疑問も生じる。流出 機構との関係性が重要であり,これについてはまだ 議論されなかったわけである。

\section{4. 土壤と風化基岩の層構造を対象とした評価}

森林で扔わわれた斜面の地下構造は, 土層と基岩 層から成り, 前者は生態系における物質循環の活発 な $\mathrm{A}$ 層とその影響の弱い $\mathrm{C}$ 層, 両者の中間の $\mathrm{B}$ 層に よって構成され, さらにC層は風化程度の異なる 様々な層に分かれる。地下構造は場所毎に多様であ り, 例えば, 京都大学桐生試験地の花崗岩斜面では, 貫入試験によって固さの急増する土層と基岩層の境 界面が $1 \mathrm{~m}$ より浅い深さに存在し, 砂質のマサと呼 ばれる土層と構造の残っている強風化岩層とが区別 できて，飽和透水係数も急変していた（Kosugi et al. , 2006）。一方, 古生層の砂岩でできた竜ノ口山試験 地の斜面での調査では, $\mathrm{A}$ 層・B層とみられる土壤 層は $20 \mathrm{~cm}$ 程度で, その下側には, 礫混じりの粘土 を含む強風化層が $2 \sim 5 \mathrm{~m}$ の厚さで存在し，その下 側の弱風化層は約 5 10 m 程度で, 土層と基岩層の 区別は明瞭ではなかった（細田・谷, 2016)。斜面水 文学の研究対象は, 地表面流, 土層内の流れ, 風化 基岩内の流れ，というように，徐々に地下深部方向
に拡大せざるを得ないことがわかってきたのである (Kosugi et al., 2011).

このように地下構造が多様で複雑だとすると, 土 壤の洪水緩和効果をどのように考えれば良いのだろ うか.ここでは, 上述の桐生試験地での評価を試み た小杉（2007）の研究を紹介する.この研究では水 みちなどによる高速排水は考慮されておらず, 試験 地斜面で詳細に測定された風化基岩層をも含む土䁃 物理性を基にした二次元飽和不飽和浸透流計算が行 われている。したがって, 浸透流説に属するといえ る.このモデルでの降雨時の流出計算は, 土層の厚 さやハイエトグラフを変えて行われて抢り。小杉 （1999）とは異なり，土壤物理性の違いが及ぼす影 響を議論するのではなく, 土層の厚さによって, 飽 和地表面流, 土層内の斜面方向への飽和浸透流, 風 化基岩への浸透流の雨水配分割合が変化することが 強調されている。 その結果, 土層の役割は, 降雨強 度変動を緩やかにならして排水強度のピークをより 小さくするバッファ効果 (本稿では平準化効果と呼 ぶ）によって, 飽和透水係数の低い風化基岩への浸透 を促進するところにあると指摘している，土層が厚 い場合は基岩浸透が増えて洪水流出緩和効果が大き いが, 土層がうすい場合は, 飽和地表面流の発生に よって鋭い流出ピークが生じるというわけである.

以上のように, 小杉 (2007) の研究の新しいとこ ろは, 土層の流出緩和における役割が土䁃物理性に よるばかりではなく, 地下構造全体での流出機構を 変化させることによることを明らかにした点にあ る。この結果は, 過度な人間の森林利用によって土 層がうすくなり，はげ山に移行する危険性を示す点 でも重要である。ただ, 地下構造の流出緩和効果が 風化基岩への浸透量を増やすことに限定されるとま ではいえないだろう。では, どういう効果としてま とめられるか.ささらに検討してゆこう。

\section{$\mathrm{V}$. 土壤の流出緩和効果の評俩に必要な キーポイント}

\section{1. キーポイントの概要}

本稿では, 土壤の流出緩和効果について, 流出機 構との関連をふまえて, これまでの研究の流れを調 ベてきた。下記の 2 課題がキーポイントとして指摘 できる。

1）降雨期間中，雨水は地中に鉛直に浸透するが, IV.2で説明したように, 土層に乾燥部分が残ってい 
る場合には雨水が貯留されて排水しない. その一方, 土層が深部まで湿潤になると降雨変動を速やかに伝 えるようになるのだが, この過程では降雨変動をな らす平準化効果が生じる。 そこで，この平準化効果 の水理学的根拠について, V.2で説明する.

2) 次に, 地下構造全体の空間的な不均質性を, どのように土壤の流出緩和効果の評価において捉え るべきかという点がキーポイントとなる．この不均 質性の影響を検討しないと，II.1の浸透能やII. 2の 保水容量がそうであったように，「こういう場合に 土壤の流出緩和効果が大きいはずだ」という推測が ひとり歩きするだけで，不均質性がかかわって，実 際上の効果は不明ということになりかねない. そこ で，土層内の不均質性とは理論的にどのように整理 できるかという点を V.3で，なぜ地下構造が不均質 なのかという点をV.4で考察し, 現時点における研 究動向を示す。前者では, 飽和帯と不飽和帯におけ る不均質性の役割のコントラストがテーマになり, 後者では, 水文学よりも時間スケールの長い流出空 間の地形や生態系の発達過程が議論される.

\section{2. 鉛直不飽和浸透流の非線形性}

森林でおおわれた斜面では, 雨水のほとんどは土 層にいったん浸透する。雨水の鉛直浸透過程では, IV.2で述べたように，不飽和透水係数が圧力水頭や 体積含水率によって数オーダーにわたって大きく変 化する。すなわち, 降雨強度の変動範囲は, しとし と雨から集中豪雨まで一見広いように思われるが, 洪水流出に寄与しない霧雨を除けば, たかだか〜 $100 \mathrm{~mm} \mathrm{~h}^{-1}$ の 100 倍程度に過ぎない。透水係数にお いて通常用いる単位に換算すると $2.8 \times 10^{-5} \sim 2.8 \times$ $10^{-3} \mathrm{~cm} \mathrm{~s}^{-1}$ の範囲である。 ところが, 土壤の透水係数 は, 飽和状態では降雨強度より大きいのに対して, 乾燥土壤でははるかに小さく, 変化幅が例えば $10^{-8}$

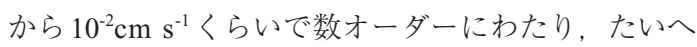
ん広い.

そこで, 降雨中の不飽和浸透流を,（1）式の基に なっているダルシーの法則を用いて説明しよう。地 表面の境界条件は, ダルシーの法則を用いて次の式 で表される。

$r=K+K \frac{\partial \psi}{\partial z}$

右辺第一項は移流項であって重力による水の下方へ の移動を表し，第二項は拡散項であって湿潤部と乾 燥部の圧力水頭や体積含水率の差を小さくするよう
に水を移動させる。計算例を図一3に示す。乾燥土 壌の表面に一定強度の降雨が与えられる場合を考え ると (図一3A), 不飽和透水係数 $K$ が降雨強度 $r$ より もはるかに小さいので，(2) 式が成り立つためには， 圧力水頭 $\psi$ が高くなって（ゼロに近づき）鉛直方向 の差を大きくしなければならない.しかし, Kがr に近づくと拡散項はゼロに近づき， $\psi$ の鉛直方向の 差が小さくなる.この $\psi$ 一定の湿潤部下側の急変部 がウェッティングフロントとなり，降雨が続くと， フロントを先端として湿潤部分が下降することにな る (Rubin and Steinhardt, 1963).

土層が下方まで湿潤になった後, 降雨強度が強く なると（図一3B），これを浸透させるために地表面 でのKがより大きくなり，この部分が下降する。し かし，すでに土層全体が湿潤になっていて，Kが大

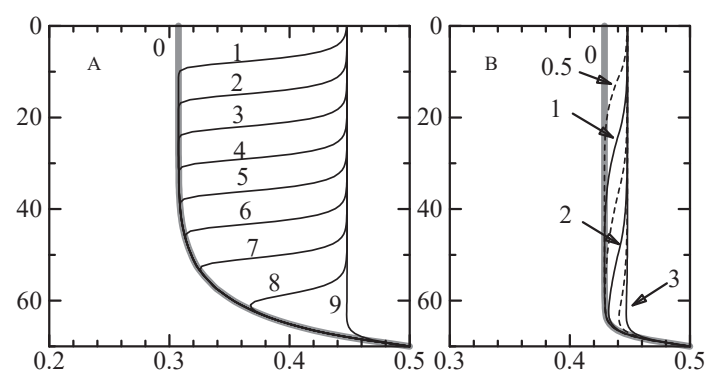

図-3 一次元鉛直チャーズ式を用いて計算された, $10 \mathrm{~mm}$ $\mathrm{h}^{-1}$ の一定降雨に対する体積含水率の時間変化 初期条件は, A が $0.05 \mathrm{~mm} \mathrm{~h}^{-1}, \mathrm{~B}$ が $5 \mathrm{~mm} \mathrm{~h}^{-1}$ の 一定降雨による定常状態である。

図中の数字は初期条件からの経過時間を示す. 計算は, 小杉式 (Kosugi, 1996) を用いたHYDRUS 1D (Šimůnek et al., 2013) によって行った。 パラ メータの值は, 飽和含水率 0.5 , 残留含水率 0.2 , 間隙の中央值に対応する圧力水頭 $-10 \mathrm{~cm}$, 間隙 の対数正規分布の標準偏差 1.7 , 飽差透水係数 $6 \times 10^{-3} \mathrm{~cm} \mathrm{~s}^{-1}$ である

Fig. 3 Temporal changes in the distribution of volumetric water content in response to constant rainfall intensity of $10 \mathrm{~mm} \mathrm{~h}^{-1}$ calculated using a one-dimensional vertical form of the Richards equation.

The initial conditions for panels A and B are, respectively, steady states with constant rainfall intensities of 0.05 $\mathrm{mm} \mathrm{h}^{-1}$ and $5 \mathrm{~mm} \mathrm{~h}^{-1}$.

Numbers indicate the time in hours from the start of rainfall.

Calculations were conducted using HYDRUS 1D (Šimůnek et al., 2013) with the Kosugi (1996) model assuming saturated water content of 0.5 , residual water content of 0.2 , the pressure head calculated from the median pore radius of $-10 \mathrm{~cm}$, the standard deviation of the lognormal distribution of soil pore radius of 1.7 , and saturated hydraulic conductivity of $6 \times 10^{-3} \mathrm{~cm} \mathrm{~s}^{-1}$. 
きく, 移流項も拡散項も大きくなっているため, 降 雨強度の変化は速やかに伝わる。乾燥時とは違い, 体積含水率をわずかに大きくするだけで，Kを新し い $r$ に等しくすることができるわけである。つまり, 不飽和浸透流に揖いては, 圧力水頭・体積含水率· 透水係数が相互依存関係にあるから, 降雨強度の変 化は, 体積含水率変動を通じて土層全体の貯留量を 変動させる。したがって, 降雨強度は速やかに土層 下部へ, さらに排水強度変動に伝達される。な扔か つ, 貯留量が変動することで, 降雨強度の変動は緩 やかにならされ，排水強度の平準化をもたらすこと になる。 この降雨から排水への波形伝播は, 水理学 に扔ける管水路との対比によると理解しやすいだろ う. すなわち, 管水路では貯留量の変化がないので, 入力流量の変動はそのままただちに出力流量に伝播 する。十分湿潤になった土壤での不飽和浸透は, 貯 留変化をともなうので, 波形変化が速やかに伝わる のに平準化されるのである.

\section{3. 不飽和浸透流の分散的, 飽和浸透流の集中的 な性格のコントラスト}

地中の水の動きは，IIの分類に示したように多様 であり, 森林でお扔われた斜面土層では, とりわけ 空間的不均質性が大きいから, その取り扱いは難し くみえる。しかし, 不均質性の雨水流出過程に及ぼ す効果は, マトリックポテンシャルが間隙に水を保 持させている不飽和帯と, 圧力ポテンシャルのか かっている飽和带とでは異なることに注意すること で，見通しがだいぶよくなる（谷, 2016b)。この点 について説明したい.

まず，大間隙やパイプ状水みちも含まれているよ うな土壤物理性の不均質な土層を対象に, 不飽和透 水係数が降雨強度に近いような湿潤状態が成立して いるような場合を考え, 降雨強度が変動するときの 鉛直不飽和浸透流の変化を検討してみよう。不飽和 帯では, サイズの小さい間隙がマトリックポテン シャルが低いので吸引力が大きく，優先的に水で満 たされる。そそのため, 降雨強度が強くなればサイズ の大きい間隙にも水がはいるようになり，弱くなれ ばサイズの大きい間隙から水が抜ける。重要な点は, サイズの小さい間隙は土壤物理性が不均質であって も，どこにでも普遍的に含まれているということで ある，そのため, 降雨強度の変動に応じて土層内の 体積含水率が変動する性質は, 土壤物理性が均質で あろうと不均質であろうと同じょうに生じ，土壤内
のローカルな体積含水率の変動が土層全体での貯留 量変動へ広がる。 その結果, 不均質であっても, 降 雨波形の変動の排水への伝播の性質は, 均質の場合 と変わらない. 土層内には大間隙やパイプ状水みち があるわけだが，その役割は次のようになるだろう。 まず，パイプ状水みちはマトリックポテンシャルが 無視できるので，そこには水がはいらず，流れに対 する役割は生じない. 大間隙を含むマトリックポテ ンシャルを持つ間隙に水がはいるかどうかは, 降雨 強度によるわけだが，サイズの大きな間隙に水がは いるほど, 流れの疎通がよくなり, 不飽和透水係数 が大きくなる。降雨がよほど強くなっても, 大間隙 が含まれている場合には, 不飽和状態を維持したま ま雨水を鉛直に浸透させることができるわけであ る. 以上のように, 不飽和帯で流れの特性に基づき, 局所的に存在する大きなサイズの間隙に流れが集中 することがなく, 降雨入力の変動が土層全体の貯留 変動を引き起こすわけで, 不飽和帯での流れのふる まいには分散的な性質があるといえる。

これに対して飽和浸透流では, 圧力ポテンシャル がかかっているいので全てのサイズの間隙が水で満 たされ，サイズが小さくなるほど流れに対する抵抗 が大きい，そのため，サイズが小さい間隙では単位 断面積流量であるフラックスが小さく, 逆にパイプ 状の水みちのような大きい間隙ほど抵抗が小さくて フラックスが大きい. 降雨強度が強くなったとする と，土の間隙でもフラックスが大きくなるのだが, 同じような割合で大きくなったとしても，もともと 流れのほとんどをを担っていたパイプ状水みちな ど, サイズの大きな間隙に扮ける増加量が絶対值と しては大きくなる.こうしたサイズの大きな間隙は, どこにでも存在するのではなく局所性が著しいか ら, 大間隙のない部分では流量が小さく, 大間隙に 流れが集中することになる.

堤ら（2005）の人工パイプを用いた斜面土層実験 では，パイプ内に水面を持つ開水路となっている場 合や，管水路となっていてもパイプ末端が湧水点な どで大気圧に接している場合は，基準面からの高さ が同じで位置水頭が等しくても，パイプ内が周囲の 土壤マトリクスよりも圧力水頭が低くなり, 水がパ イプ内に集中していた。したがって，飽和帯では， 抵抗の少ない大間隙へ水が集まり, 流れのふるまい に集中的な性質がみられる.

このように, 不飽和帯と飽和帯とでは, その物理 的な原理に基づいた流れのコントラストが存在し， 
空間的な不均質性の取り扱いが異なることに注意し なければならない。そのため, 不飽和帯の場合には, 土壤の物理性が流出に及ぼす効果は, 土層全体の貯 留量を通じて現れるが, 飽和帯の場合は, 土層の中 に，パイプ状水みちがどのように含まれているのか で大きく変化する，大胆にいえば，不飽和帯では， 水みちがあってもなくてもその影響を受けにくく, 圧力水頭・体積含水率. 不飽和透水係数の関係で表 される土層全体での平均的な保水・透水特性が降雨 流出応答に㧍いて支配的となる。しかし, 飽和帯で は, 土壤の保水・透水特性の影響は小さくなり, 水 みちの有無が流出応答に決定的な差異をもたらす。 結果的に, 水みちが発達していれば飽和帯での貯留 変動は無視できて, 不飽和帯での浸透流だけが降雨 流出応答に影響を及ぼすことになる。すでに述べて きた「水みち説」はこうした飽和帯の性質を反映し たものといえるわけである.

\section{4. 土層発達過程からの不均質性の理解}

IV.2で紹介した水みち説と浸透流説とでは，前節 で説明したように，降雨流出応答に扔ける飽和帯に 扔ける流れの影響を大きく変化させる。では，実際 の森林斜面ではどちらの説が主に成り立つのだろう か. これについては, 詳細な試験斜面での調查展開 が今後必要であるが, 日本のような湿潤変動帯（塚 本, 1998）では, 水みち説がメジャーだと現時点で 推測できる。なぜなら，侵食外力に抵抗して土層が 発達して数百年以上の後に崩壊するという地形学的 な長期の繰り返し過程に水みちでの地下水排水が必 要と考えられるからである (谷, 2016a)。すなわち, 崩壊跡には植生が侵入して裸地面を扮抒いつくし, 以後, 土層が厚くなってゆく（下川, 1983）。しかし, その長期過程には豪雨が何度も起こるにもかかわら ず，土層が崩壊せずに厚くなってゆくためには，地 表付近に集中する植生根系では, 斜面安定の観点か らは十分とはいえない.

斜面安定に関する地形学分野での研究では, 土圧 による土壤ブロックの摩擦抵抗を考慮したDietrich, et al.（2008）の研究を基に, Milledge et al. (2014) が, 根系と土圧が崩壊の水平方向と深度方向の空間 スケールに及ぼす影響を検討している。この研究に 基づけば, 土層が地下水で飽和する場合には斜面安 定条件は低下し, その条件が最低となる空間スケー ルで崩壊が発生する可能性が最も高くなる。一方, 斜面土層全体で降雨がほとんどすべて洪水流出量に
まわるような豪雨は, 数百年の時間スケールでは何 度も発生する。それゆえ, 斜面の緩やかな部分で飽 和地表面流が発生するのは当然であろうが, 急傾斜 部を含む斜面全体で地下水面が上昇する状態での斜 面安定の維持は困難だと, 筆者は考える。湿潤変動 帯の急斜面での土層発達は, 水みちを通した飽和帯 の地下水排水による地下水面上昇抑制が支えている と言わざるを得ない.

V. 3では, 飽和浸透流の集中的な性格について説 明した。斜面地形の発達は, 土層発達と崩壊の輪廻 のよりも長い時間スケールでの現象なので, 崩壊発 生直後から土層が厚くなってゆく千年程度の期間で は, 雨水の集中する斜面下部やゼロ次谷の凹地形に, 恒に雨水が集まりやすいと考えられる。それゆえ， 雨水集中部での地下侵食が起こりやすく（新藤, 1993）, これによって土層と水みちの coevolution（共 進化）が進行するのではないかと推測される。よっ て, 少なくとも, 土䁃物理性が均質な土層が発達す ることは想定しにくく, 水みち説が現実に近いと考 えられる。

\section{VI. 流出緩和効果研究の最前線}

\section{1. 狭義の森林土壤効果の評価}

IIでは, 土畩間隙を大間隙とパイプ状水みちに区 別したが，前者は，V.4で述べたように土層と共進 化するものと考えられる。これに対して, 大間隙は, 生態系のさまざまな生物学的過程を経て形成される と推測される。これこそが, 森林が直接産み出した 間隙であり， III. 2 で説明した保水容量の研究におい ても，その効果が想定されていたのではないだろう か. 水みち説が成り立つとすると, この狭義の森林 土壤の効果も斜面や流域に扔ける流出に現れるもの と考えられる。 そこで, この流出緩和に対する狭義 の森林土壌の効果について, ここで考えておきたい. 有光（1992）によれば, 生物の遺体が土壤動物 · 微生物によって破砕. 分解され, 無機物や腐植と呼 ばれる有機物になって, 基岩から生成される風化砕 屑物が化学変化して生じる粘土鉱物と混和結合する ことによって，土壤となる。この土壤生成過程は, 崩壊後に植物が侵入して土層が発達するとともに進 むと考えられる。しかし，こうした生物活動によっ て生成されるサイズの大きな間隙は, パイプ状水み ちが飽和浸透流の集中にともなう地下侵食によって 形成されるのとは異なり, 地表面付近に多く, 深部 
に少なくなるような鉛直層構造を発達させる。腐朽 した根系跡のような連続した線状の間隙も形成され るとしても，パイプ状の結合した間隙が侵食によっ て局所的に太くなってゆくのではなく，地表面に近 いほど活発なさまざまな生物活動の結果としてラン ダムに分布すると推測される。

とはいえ，たといランダムに大間隙が分布すると しても, 土壤のどの部分でも均等に含まれるという わけではないので, 土壤サンプルのサイズが小さい と，大間隙が含まれたり含まれなかったりするばら つきが大きくなる。したがって，大間隙を含む土壤 を代表するには大きなサイズのサンプルで土壤物理 性を試験する方がよいと考えられる。大手ら (1989) はこうした考えの基に, 直径 $19.5 \mathrm{~cm}$ で長さ $78 \mathrm{~cm}$ の 不攪乱土壤サンプルで, 森林土壤の飽和と不飽和の 透水係数を調べた。 その結果, 圧力水頭で $-10 \mathrm{~cm}$ 程 度の值よりも飽和に近い範囲で不飽和透水係数が急 激に大きくなること, その傾向が地表面に近いほど 著しくなることを明らかにした。このような性質は, 自然土䁃で一般的に認められるので (Mohanty et al., 1997; Jarvis, 2008),このような飽和近傍における毛管 力を持つ大間隙の存在を前提として, 森林土壤の流 出に及ぼす影響を考えなければならないことになる。

森林土壤の浸透能が降雨強度よりも大きい傾向 は，正.1で示したように古くから指摘されてきたわ けであるが, 土壤に浸透した雨水が洪水流出のピー クを低くする効果については, これまであまり論じ られてこなかった。本稿では，V.2で不飽和鉛直浸 透流によってこの効果が発揮されることを説明し た. 1 時間に $50 \mathrm{~mm}$ を超えるような豪雨においては, それを鉛直浸透させるには大間隙の存在が重要で あって, 圧力水頭は $-10 \mathrm{~cm}$ よりさらにゼロに近い值 になり, 降雨変動を体積含水率の変動によって受け 止めて，変動を平準化するものと考えられる。大雨 での森林土壤の効果が, 水みち説を前提としたうえ で発揮されるとみることができるわけである.

\section{2. 斜面条件一般の洪水流出緩和への影響評価手法}

これまでの検討では, 土壤の保水・透水特性で表 される土壤物理性を支配する間隙分布が，斜面の流 出緩和にどのように効果を及ぼすことができるのか に注目してきた。 ところが，溪流や河川の流出特性 が，土壤物理性を含むさまざまな斜面条件によって どのように量的影響を受けるのか，という課題に回 答を与えているとはいえない.わかりやすく説明し
たい

いま, 土䁃物理性, 土層の厚さ, 斜面勾配, 斜面 長などが異なっているふたつの斜面を考える. 流出 特性の何らかの指標に対して, 土壤物理性の違いは, その他の条件に比してどの程度大きいのか, あるい は小さいのだろうか，質の異なる要因のセンシティ ビティーを比較することは一般に容易ではない，林 業や森林開発に対するゾーニングを行う場合,「土 壤間隙の違いの影響」だけが提示されても, その他 の条件の影響と比較できないと評価の実用性が低い.

幸いにして, 土層全体が湿潤な場合の洪水流出応 答については, 被説明指標が比較的容易に決定でき る。というのは, 谷 (2016b) で詳しく論じたよう に，降雨が十分に供給されて土層全体が湿潤になる と, それ以降の降雨総量と洪水流出総量は近似的に 相等しくなり，降雨波形の流出波形への変換過程は， 流出強度と土層貯留量との関係が一対一の関係を持 つ孔のあいた一段タンクモデルで近似できるからで ある。そのタンクモデルは, 土層全体の貯留量を $V$, 流出強度を $q$ として次の水収支式で表される。

$\frac{d V}{d t}=r-q$

で表される。このモデルは, 降雨強度と流出強度が 等しい定常状態での流出強度と貯留量の関係が, 非 定常条件でも厳密に成り立つという意味で, 準定常 変換システムと呼ばれる（Tani, 2013；谷, 2016a）.

（3）式を変形すると

$\frac{d q}{d t}=\frac{r-q}{d V / d q}$

となり, 流出強度の上昇下降の速さが, 定常時にお ける土層貯留量の流出強度に対する微分係数 $d V / d q$ に依存することになる, つまり, 流出強度に対して 貯留量が大きく変動する場合に流出強度が上下に変 動する速度が小さくなって, 八イドログラフがなら され，ピークが低くなるわけである。したがって， 同じような降雨強度が長く続いて, 定常に近い状況 に近づく場合は, 流出強度が降雨強度とほぼ同じに なってピーク強度を低下させることはできない（佐 山, 2017).こうした効果の限界も指摘しておきたい.

Tani（2013）は, $d V / d q$ を流出平準化指標（Index of runoff buffering potential）と呼び，それに対する, 土壤物理条件, 土層の厚さ, 斜面勾配, 斜面長, パ イプ状水みちによって飽和透水係数が大きくなる割 合の各変数のセンシティビティーを評価する手法を 開発した。こうした解析は一般性が求められるため, 
条件と指標は無次元化変数として処理されている. そのため理解しにくい部分もあろうが, 拙著 (谷. 2016a）にも詳述しているので, 本稿では, 「流出平 準化指標を説明対象とする諸条件のセンシティビ ティーアナリシス」という評価枠組みとその実用的 な意義のみを記述するにとどめたい．

\section{VII. おわりに}

森林は流出変化を緩和すると言われ，日本社会で は常識的に信じられている一方, 研究面では明確な 論点が示されてこなかった。本稿では, 従前からの 土壤の物理性が流出緩和効果をもたらすとの考え方 を基に，どのようなメカニズムを通じてそれが現れ るのか, どのような場合に，限界に達して効果が発 揮されなくなるのかを検討した。

筆者が従来より指摘しているように, 降雨流出応 答に対する流域条件の影響は, 降雨量の洪水流出と 基底流出への配分と, 降雨波形の流出波形への変換 を通じて現れる（谷, 2012）。これについては，不飽 和透水係数が強い非線形性を持つためであることを 説明した。また，土層内の不均質性に関しては，生 物作用で地表面付近に多く形成される大間隙と流れ の集中によって発達するパイプ状水みちが区別され ることを述へ，前者は狭義の森林土壤としての流出 緩和効果を高めること, 後者は飽和地表面流の発生 を抑制し，鉛直不飽和浸透流に扔ける流出緩和効果 をそのまま斜面からの流出に伝えるうえで効果があ ることを説明した。こうした不均質性の効果が生じ るのは, 不飽和浸透流の分散的, 飽和浸透流の集中 的という性格の違いが重要なはたらきをするからで あることも指摘した。

水みちが形成されないならば，土層は地下水面が 上昇し, 洪水流出は飽和地表面流によって産み出さ れる。しかし, 湿潤変動帯では, 斜面安定の観点か ら現実的ではなく, 土層とパイプ状水みちの共進化 が想定され, 結果的に, 間隙分布に基づく土壤の物 理性が流出緩和効果として現れることを説明した。 これを確かめるには, 今後の研究が必要であるが, 斜面流出機構を, 浸透流説と水みち説で捉えたとき に, 土壤の効果が異なることは十分理解して扔かな ければならない.

さらに, 森林管理においては, 土壤物理性以外の 斜面条件のそれぞれが流出に及ぼす影響を定量的に 評価比較しなければならないことを説明し，そのた
めの流出平準化指標への斜面条件のセンシティビ ティーアナリシスの手法を簡単に紹介した。 土䁃の 効果もその中のひとつとして理解してゆくことが重 要なのである.

最後に, 森林管理に関する時間スケールの視点を 強調しておきたい. 本稿の最初に述べた蒸発散の効 果は，伐採や樹木成長によって短期間に変化する. しかし, 大間隙は数十年以上の生態系における生物 活動の結果として, パイプ状水みちは数百年以上の 土層発達過程の結果として, 長期間かけて徐々に形 成される。したがって, 森林の資源利用や保護など を考えるときは, この時間スケールの観点を意識せ ざるを得ない，たとえば，渇水期間の水資源を確保 するには，森林伐採を短期的に繰り返すことが効果 的な対策である。一方, 急傾斜斜面からの流出は, 土層が崩壊しない限り数百年以上の期間にわたって 継続的に土壤効果によって緩和される。森林を利用 しながら保全するのに具体的にどうすれば良いかは 簡単な課題ではないが, 森林の蒸発散や土壤の流出 緩和の特性を十分理解しておくことは, 不可欠であ る。本稿はそのための序説として位置付けられれば 幸甚である.

\section{謝辞}

本稿作成にあたっては, 2011～2015年度の科学研 究費基盤 $(\mathrm{S})\lceil$ 地形・土壤・植生の入れ子構造的発 達をふまえた流域水流出特性の変動予測」(代表: 谷誠), 及び米国の Coca-Cola Foundation（コカ・コー ラ財団）「Evaluation Study of Forest Impacts on the Water Cycle and Climate Change（森林が水循環㧍よび 気候変動に与えるインパクト)」(代表：小杉緑子京 都大学農学研究科教授）の支援を受けた.

\section{引用文献}

有光一登. 1992. 森林土壤の形成とその特長. 森林水文学 (塚本 良則編), 文永堂出版; 19-36.

Beven K, Germann P. 2013. Macropores and water flow in soils revisited, Water Resources Research 49: 3071-3092, DOI: 10.1002/wrcr.20156.

Bosch JM, Hewlett JD. 1981. A review of catchment experiments to determine the effect of vegetation changes on water yield and evapotranspiration. Journal of Hydrology 55: 3-23.

Bradshaw CJA, Sodi NS, Navjot S, Peh KSH, Brook BW. 2007. Global evidence that deforestation amplifies flood risk and severity in the developing world. Global Change Biology 13: 2379-239, doi: 10.1111/j.1365-2486.2007.01446.x.

Brutsaert W. 1994. The unit response of groundwater outflow from a hillslope. Water Resources Research 30: 2759-2763. 
Brutsaert W. 2005. Hydrology: An Introduction. Cambridge University Press: Cambridge; 618.

Calder IR. 1999. The Blue Revolution: Integrated land and Water Resources management. Earthscan: London; 353 (蔵 治光一郎訳 2008. 水の革命-森林·食糧生産・河川・流域圏の統 合的管理. 築地書館; 269).

チャペル ニック A. 2005. 湿潤地帯の森における水の流出: 神話 vs.観測結果. 水利科学40 (6) :32-46.

Dietrich WE, McKean J, Bellugi D, Perron T. 2008. The prediction of shallow landslide location and size using a multidimensional landslide analysis in a digital terrain model, Proceedings of the Fourth International Conference on Debris-Flow Hazards Mitigation. IOS Press: Amsterdam; 12.

Dunne T, Black RD. 1970. Partial-area contributions to storm runoff in a small New England watershed, Water Resources Research 6: 1296-1311.

藤枝基久. 2007. 森林流域の保水容量と流域貯留量. 森林総合研 究所研究報告403:101-110.

Freeze RA. 1972. , Role of subsurface flow in generating surface runoff, 2. Upstream source areas. Water Resources Research 8: 1272-1283.

Gomi T, Asano Y, Uchida T, Onda Y, Sidle, RC, Miyata S, Kosugi K, Mizugaki S, Fukuyama T, and Fukushima T. 2010. Evaluation of storm runoff pathways in steep nested catchments draining a Japanese cypress forest in central Japan: a hydrometric, geochemical, and isotopic approaches, Hydrological Processes 24: 550-566, DOI:10.1002/hyp.7550.

Harman C, Sivapalan M. 2009. A similarity framework to assess controls on shallow subsurface flow dynamics in hillslopes, Water Resources Research 45, DOI: 10.1029/ 2008WR007067.

Hewlett JD, Hibbert AR. 1967. Factors affecting the response of small watersheds to precipitation in humid areas. In Forest hydrology, Sopper WE, Lull HW (eds). Pergamon Press: New York; 275-290.

Horton, RE. 1933. The role of infiltration in the hydrological cycle. Transaction of American Geophysical Union 14: 446460.

細田育広・谷 誠. 2016. 古生層堆積岩小流域の厚い風化基岩層に おける水分変動が降雨流出応答に及ぼす影響. 地形37:465-492. 石原藤次郎·石原安雄・高棹环馬・頼 千元. 1962. 由良川の出水 特性に関する研究. 京都大学防災研究所年報5A：147-173.

Iwasaki K, Katsuyama M, Tani M. 2015. Contributions of bedrock groundwater to the upscaling of storm-runoff generation processes in weathered granitic headwater catchments, Hydrological Processes 29: 1535-1548, DOI: 10.1002/hyp.10279.

Jarvis, N. 2008. Near-saturated hydraulic properties on macroporous soils. Vadose Zone Journal 7: 1302-1310, DOI: 10.2136/vzj2008.0065.

加藤博之・福嶌義宏・鈴木雅一. 1975. 山腹斜面の流出機構につい て (1) ライシメーターと表層流出量について. 京都大学演習林報 告47:74-85.

Kirkby MJ. 1978. Hillslope Hydrology. Wiley: Chichester; 389. 北原 矅. 1994. 森林土層中の水移動におけるパイプ孔隙の特性 に関する研究. 森林総合研究所報告367:63-115.

小松 光・篠原慶規・大槻恭一. 2013. 管理放棄人工林は洪水を助 長するか. 水利科学56 (6) :68-90.

Komatsu H, Rappleye J. 2017. Incongruity between scientific knowledge and ordinary perceptions of nature: An ontological perspective for forest hydrology in Japan. Journal of Forest Research 22, 75-82. DOI: org/10.1080/13416979.2017.1283977.

Kosugi K. 1996. Lognormal distribution model for unsaturated soil hydraulic properties, Water Resources Research 32: 2697-2703.

小杉賢一朗. 1999. 森林土壤の雨水貯留能を評価するための新た な指標の検討. 日本林学会誌 $81: 226-235$.

小杉賢一朗. 2007. 森林の水源涵養機能に土層と透水性基岩が果 たす役割の検討. 水文·水資源学会誌20:201-213.

Kosugi K, Fujimoto M, Katsura S, Kato H, Sando Y, Mizuyama T. 2011. Localized bedrock aquifer distribution explains discharge from a headwater catchment. Water Resources Research 47, DOI: 10.1029/2010WR009884.

Kosugi K, Katsura S, Katsuyama M, Mizuyama T. 2006. Water flow processes in weathered granitic bedrock and their effects on runoff generation in a small headwater catchment, Water Resources Research 42, DOI10.1029/2005WR004275.

窪田順平・福嶌義宏·鈴木雅一. 1987. 山腹斜面における土壤水分 変動の観測とモデル化. 日本林学会誌69:258-289.

Laurance WF. 2007. Forests and floods. Nature 449: 409-410. DOI: 10.1038/449409a.

Liang WL, Kosugi K, Mizuyama T. 2011. Soil water dynamics around a tree on a hillslope with or without rainwater supplied by stemflow. Water Resources Research 47, DOI: 10.1029/ 2010WR009856.

真下育久. 1960. 森林土壤の理学的性質とスギ・ヒノキの成長に関 する研究. 林野土壤調査報告11:1-185.

McDonnell JJ. 1990. A rationale for old water discharge through macropores in a steep, humid catchment. Water Resources Research 26: 2821-2832.

McDonnell JJ, Beven K. 2014. Debates - The future of hydrological sciences: A (common) path forward? A call to action aimed at understanding velocities, celerities and residence time distributions of the headwater hydrograph. Water Resources Research 50: 5342-5350, DOI: 10.1002/2013WR015141.

Milledge DG, Bellugi D, McKean JM, Densmore AL, Dietrich WE. 2014. A multidimensional stability model for predicting shallow landslide size and shape across landscapes, Journal of Geophysical Research, Earth Surface 119: 2481-2504, DOI: 10.1002/2014JF003135.

Mohanty BP, Bowman RS, Hendrickx JMH, van Genuchten MTh. 1997. New piecewise-continuous hydraulic functions for modeling preferential flow in an intermittent floodirrigated field. Water Resources Research 33: 2049-2063.

Mosley MP. 1979. Streamflow generation in a forested watershed, New Zealand. Water Resources Research 15: 795-806.

村井 宏・岩崎勇作. 1975. 林地の水および土䁃保全機能に関する 研究 (第1報) 森林状態の差異が地表流下, 浸透および侵食に 及ぼす影響. 林業試験場研究報告274:23-84.

虫明功臣. 1981. 利根川水源山地の水資源特性. アーバンクボタ 19:46-51.

虫明功臣・高橋 裕. 安藤義久. 1981. 日本の山地河川の流況に及 ぼす流域の地質の効果. 土木学会論文報告集309:51-62.

太田岳史・福嶌義宏・鈴木雅一. 1983. 一次元鉛直不飽和浸透を 用いた雨水流出特性の検討 : 日本林学会誌 $65: 125-134$.

大手信人.鈴木雅一・窪田順平. 1989. 森林土壤の水分特性 (I) 飽 和-不飽和透水特性の鉛直分布測定法と2,3の測定結果, 日本 林学会誌71: 137-147. 恩田裕一. 2008. 人工林荒廃と水土砂流 出の実態. 岩波書店; 245 .

Pearce AJ, Stewart MK, Sklash MG. 1986. Storm runoff 
generation in humid headwater catchments: 1 . Where does the water come from? Water Resources Research 22: 12631272.

Rubin J, Steinhardt R. 1963. Soil water relations during rain infiltration I. Theory. Soil Science Society of America Journal 27: 246-251.

佐山敬洋・田中茂信·寶 馨. 2017. 分布型流出モデルと時空間起 源追跡法による鬼怒川洪水の流出解析. 水文・水資源学会誌 30 : 161-172.

下川悦郎. 1983. 崩壊地の植生回復過程. 林業技術496:23-26.

Sidle RC, Ziegler AD, Negishi JN, Abd. Rahim Nik,. Siew R, Turkelboom F. 2006. Erosion processes in steep terraintruths, myths, and uncertainties related to forest management in Southeast Asia. Forest Ecology and Management 224 (1): 199-225.

志水俊夫.1980. 山地流域における渇水量と表層地質・傾斜・植生 との関係. 林業試験場研究報告310:90-128.

Šimůnek J, Šejna M, Saito H, Sakai M, van Genuchten MT. 2013. The Hydrus-1D Software Package for Simulating the Movement of Water, Heat, and Multiple Solutes in Variably Saturated Media, Version 4.17, HYDRUS Software Series 3, Department of Environmental Sciences, University of California Riverside, Riverside: California, USA; 342.

椎葉充晴·立川康人·市川 温. 2013. 水文学·水工計画学. 京都大 学学出版会; $615 p$.

新藤静夫. 1993. 災害とその予測 第四紀研究の果たす役割-斜 面災害における地中水の集中流現象. 第四紀研究32:315-322.

鈴木雅一. 1984a. 山地小流域の基底流出派減特性 (I) 飽和-不 飽和浸透流モデルを用いた数式的検討. 日本林学会誌 66 : 174182.

鈴木雅一1984b. 山地小流域の基底流出逓減特性（II) 蒸発散量 が流出逓減に与える影響. 日本林学会誌 $66: 211-218$.

Swank WT, Douglass JE. 1974. Streamflow greatly reduced by converting deciduous hardwood stands to pine. Science 185: 857-859, DOI: 10.1126/science.185.4154.857.

立川康人·江崎俊介・椎葉充晴・市川 温. 2009. 2008年7 月都賀川 増水における局地的大雨の頻度解析・流出解析と事故防止に向 けた技術的課題について. 京都大学防災研究所年報 52B:1-8.

高木不折・松林宇一郎. 1979. 遅い中間流出・地下水流出の非線 形性について. 土木学会論文報告集283:45-55.

高棹㻟馬. 1963. 出水現象の生起場とその変化過程. 京都大学防 災研究所年報 $6: 166-180$.

谷 誠. 1982. 一次元鉛直不飽和浸透によって生じる水面上昇の特 性. 日本林学会誌64:409-418.

谷 誠. 1985. 山地流域の流出特性を考慮した一次元鉛直不飽和 浸透流の解析. 日本林学会誌 67:449-460.

Tani M. 2008. Analysis of runoff-storage relationships to evaluate the runoff-buffering potential of a sloping permeable domain. Journal of Hydrology 360: 132-146, DOI:10.1016/j.jhydrol. 2008.07.023
Tani M. 2013. A paradigm shift in stormflow predictions for active tectonic regions with large-magnitude storms: generalisation of catchment observations by hydraulic sensitivity analysis and insight into soil-layer evolution. Hydrology and Earth System Sciences 17: 4453-4470, DOI: 10.5194/hess-17-4453-2013.

谷 誠. 2012. 森林の保水力はなぜ大規模な豪雨時にも発揮される のか? -その1 洪水緩和にかかわる二種の効果の区別-. 森林科 学66:26-31.

谷 誠. 2013. 洪水流出のモデル化を圧力伝播の観点から捉え直 す. 水文·水資源学会誌 $26: 140-152$.

谷 誠. 2016a. 水と土と森の科学. 京都大学学術出版会;243.

谷 誠. 2016b. 複雑な斜面流出機構が単純な降雨流出応答を産み 出す根拠. 地形37:531-557.

谷 誠. 2017. 森林利用と環境保全の両立に関する研究の必要性. 森林科学 $80: 56-57$.

谷 誠·細田育広. 2012. 長期にわたる森林放置と植生変化が年蒸 発散量に及ぼす影響. 水文・水資源学会誌 $25: 71-88$.

谷 誠·玉井幸治·鶴田健二·野口正二. 2017. 日本森林学会企画シ ンポジウム報告「収穫期を迎えた人工林における資源循環利用 と水土保全との両立」. 森林科学80:42-45.

Torres R, Dietrich WE, Montgomery DR, Anderson SP, Loague K. 1998 Unsaturated zone processes and the hydrologic response of a steep, unchanneled catchment. Water Resources Research 34: 1865-1879.

Troch P, Paniconi C, van Loon EE. 2003. Hillslope-storage Boussinesq model for subsurface flow and variable source areas along complex hillslopes: 1. Formulation and characteristic response. Water Resources Research 39, DOI: 10.1029/2002WR001728.

Tromp-van Meerveld HJ, McDonnell JJ. 2006. Threshold relations in subsurface stormflow: 2 . The fill and spill hypothesis. Water Resources Research 42. DOI: 10.1029/2004WR003800.

塚本良則. 1998. 森林·水・土の保全-湿潤変動帯の水文地形学. 朝倉書店; 138

塚本良則・峰松浩彦・丹下 勲. 1988. 斜面の表層に発達する地中 パイプ. 波丘地研究7:268-280.

Tsukamoto Y, Ohta T. 1988. Runoff processes on a steep forested slope. Journal of Hydrology 102: 165-178.

堤 大三・宮峙俊彦・藤田正治・Sidle RC. 2005. パイプ流に関す る数値計算モデルと人工斜面実験による検証. 砂防学会誌 58 : 20-30.

上野 董・南 基泰. 2016. 土岐川·庄内川源流 森の健康診断, 恵 那の森からの学び. 風媒社; 72.

八幡敏雄. 1975. 土壤の物理. 東京大学出版会; 181 .

（受付：2017年7月 16 日，受理：2017年 12 月 6日） この論文への討議・コメントを, 2018年9月末日 まで受け付けます。 


\title{
Review of Forest Soil Mitigation Effects on Stream Runoff
}

\author{
Makoto TANI ${ }^{\dagger}{ }^{\dagger}$ \\ 1) University of Human Environments \\ (6-2, Kamisanbonmatsu, Motojukucho, Okazaki, Aichi, 444-3505, Japan) \\ ${ }^{\dagger}$ Corresponding Author E-mail : m-tani@uhe.ac.jp
}

Methods to evaluate forest soil mitigation effects on stream runoff are presented in this review paper. After introducing the prevailing orthodoxies derived from infiltration capacity and water holding capacity, we traced development of the methods along with elucidation of hillslope runoff mechanisms. The effects of forest are based upon soil-water retention properties and permeability originating from the distributions of soil pore radius, but two effects were produced from them: a reduction effect of stormflow volume compared with a given storm-event rainfall volume through water absorption in soil, and an attenuative effect decreasing the maximum stormflow rate through equalization of its temporal change. The latter effect was modified by additional flow mechanisms through pipe-like preferential pathways and a weathered bedrock layer under the soil layer. Such soil effects described above, however, might be valid considering the evolution of large pores through biological processes and the evolution of preferential pathways through soil-layer development.

Key words : Forest influences, Soil physical properties, Runoff mitigation, Hillslope hydrology, Heterogeneity 